\title{
The Isolation of Nitrosomonas europaea in Pure Culture
}

\author{
BY JANE MEIKLEJOHN \\ Soil Microbiology Department, Rothamsted Experimental Station, \\ Harpenden, Hertfordshire
}

SUMMARY : Nitrosomonas europaea (Winogradsky) was isolated in pure culture from Rothamsted soil. The method used entailed: (1) building up the population of nitrifiers in enrichment cultures; (2) removal of the cells from the chalk in an enriched culture with a stream of carbon dioxide; (3) picking colonies from poured silica gel plates.

The isolation of nitrifying bacteria in pure culture was first accomplished by Winogradsky (1890); it had been known for some years before that nitrification was carried out by living organisms (Schloesing \& Müntz, 1877), but attempts to isolate the organisms by the usual bacteriological methods had failed (Frankland \& Frankland, 1890). Winogradsky, whose brilliant insight had led him to the discovery of the autotrophic mode of life of the sulphur and ironoxidizing bacteria, decided that the nitrifiers must also be autotrophic, and thus succeeded in isolating them by the use of media free from organic matter. At first he used his 'negative plate' method, inoculating gelatin plates and picking off from the areas where no growth could be seen. But he soon abandoned this method (1891), and obtained pure cultures by an improved technique.

He made enrichment cultures from soil on a liquid mineral medium containing an ammonium salt and a carbonate, which were renewed as they were used by the growing cultures. After a time motile bacteria appeared in the cultures, and poured plates were then made on an entirely new inorganic solid medium, silica gel. The small colonies which developed in the plates were picked off into sterile liquid mineral medium.

Warington (1891) discovered that two species were concerned in nitrification, one oxidizing ammonia to nitrite, the other oxidizing nitrite to nitrate. In 1892, Winogradsky described two bacteria, Nitrosomonas and Nitrosococcus, which oxidized ammonia, and one, Nitrobacter, which oxidized nitrite. In the next few years, together with Omeliansky (1899a), Winogradsky isolated nitrifiers from soil samples from every continent. A species from Swiss and French soils was given the name Nitrosomonas europaea (Winogradsky, 1904).

The reasons why nitrifying bacteria are difficult to isolate are fully described in Winogradsky's papers $(1890,1891)$. In the first place, nitrifiers grow very slowly, and any contaminants in enrichment cultures grow faster. It is impossible to obtain pure cultures by simple serial transfers in liquid medium; after as many as fifty transfers (Gibbs, 1919) contaminants persist, presumably living on organic matter synthesized by the nitrifiers. Secondly, nitrifiers adhere to the solid carbonate in the medium, and not all strains have a motile stage to liberate them into the liquid. Thirdly, silica gel, which is difficult to make up, is the only suitable solid medium for isolating ammonia oxidizers, and the 
colonies formed on it are so small (diameter $100 \mu$. or less) that they cannot be seen, far less picked off, without a lens.

Winogradsky's method has been successfully used by the following authors: Boullanger \& Massol (1903), Bonazzi (1919), Gibbs (1919), Nelson (1931) and Kingma Boltjes (1934, 1935). The last three workers used a micromanipulator to pick colonies, and Nelson and Kingma Boltjes used it to pick single cells. Kingma Boltjes obtained a pure culture of $N$. europaea, and his description of the species corresponds to that of Winogradsky (1904).

Án entirely different method of isolation was used by Heubült (1929), Engel \& Skallau (1937) and Bömeke (1939); they prepared enrichment cultures on mineral medium, made a very high dilution of the culture, put it in a shaker for an hour, and made a large number of subcultures into liquid medium; in one case sixty subcultures were made, of which five were pure. Rubentschik (1929) used gypsum blocks (Omeliansky, 1899b). Hanks \& Weintraub (1936) spread high dilutions of enrichment cultures over the surface of silica gel plates, and picked the colonies with a micropipette. Tchan (1947) used a similar method; he sterilized the plates with ultra-violet light, and picked single cells with a micromanipulator.

A very much simplified method of growing nitrifying bacteria was described by Winogradsky \& Winogradsky in 1933. They inoculated silica gel plates, 'enamelled' with a dried suspension of carbonate, with soil crumbs. When haloes appeared in the carbonate film, the growth was picked off and dilutions spread on the surface of fresh silica gel plates. This method has been criticized by Kingma Boltjes (1935), and by Hanks \& Weintraub (1936), as being unlikely to give pure cultures; and indeed it is evident from a later paper by Winogradsky (1935) that it was never intended to do so. Winogradsky regarded his cultures as suitable for studies on nitrification, but not as pure in the usual bacteriological sense of the word. The method has been further criticized by Imšenecki (1946), who said that the organism described by Winogradsky \& Winogradsky as Nitrosocystis is not really a nitrifier at all, but a myxobacterium. He claimed that the nitrification observed on plates where Nitrosocystis was growing was caused by Nitrosomonas, which developed first and was later overgrown by the myxobacteria, which used the organic matter synthesized by the true nitrifier.

\section{EXPERIMENTAL}

\section{Method}

The method used here for the pure culture isolation of Nitrosomonas spp. was a modification of Winogradsky's method (1891), and had three essential steps. The first was to build up an enrichment culture till it contained an adequate number of cells. The second step was the separation of the cells from the mass of carbonate at the bottom of the culture; Winogradsky (Omeliansky, 1899 a) took advantage of the motile stage in his cultures, but my cultures did not 'show a motile stage, and I therefore 'blew' the cells off the carbonate with a stream of carbon dioxide. The third step was the making of poured plates of silica gel; it is impossible to streak on silica gel because it splits; and it seems 
most unlikely that pure cultures can be obtained by spreading a liquid inoculum over the surface of a plate.

Enrichment culture. An enrichment culture for nitrifying bacteria was started by adding $4 \mathrm{~g}$. of freshly collected surface soil from the farmyard manure plot on Broadbalk field, to $25 \mathrm{ml}$. of medium $A$ in a $250 \mathrm{ml}$. conical flask, and incubating at $25^{\circ}$.

Medium $A$ was made as follows: $\left(\mathrm{NH}_{4}\right)_{2} \mathrm{SO}_{4}, 0 \cdot 1 \mathrm{~g}$; $\mathrm{K}_{2} \mathrm{HPO}_{4}, 0 \cdot 1 \mathrm{~g}$.; NaCl, 0.2 g.; $\mathrm{MgSO}_{4} .7 \mathrm{H}_{2} \mathrm{O}, 0.05 \mathrm{~g}$.; $\mathrm{FeCl}_{3}$, trace; $\mathrm{CaCO}_{3}, 1.0 \mathrm{~g}$.; tap water, $100 \mathrm{ml}$.; sterilized by autoclaving for $15 \mathrm{~min}$. at $15 \mathrm{lb}$. It was modified from the classical medium of Winogradsky (Kingma Boltjes, 1935), calcium carbonate and tap water replacing the basic magnesium carbonate and distilled water of the original.

The progress of nitrification, in this culture and the transfers from it, was followed by observing the appearance and disappearance of nitrite in samples of the medium. This was done with Griess-Ilosvay reagent by a drop-plate method. Four drops of liquid, removed with a Pasteur pipette, were added to one drop of the reagent, and the colour produced compared with the colours given by a set of dilutions of a standard solution of sodium nitrite, containing $2,5,10,20,50,75$ and $100 \mathrm{mg}$./l. of nitrite nitrogen. When nitrite was absent from the sample, a rough test for nitrate was made by adding a knife-point of zinc dust to the sample and reagent (ZoBell, 1932).

Nitrification progressed rapidly in the enrichment culture; nitrite was formed at first, and then, after 14 days' incubation, no nitrite was found, but only nitrate. The quantities of nitrite formed by the transfer cultures on liquid media were much more than traces, $100 \mathrm{mg}$./1. being formed in 4-7 days, and all disappearing, with the formation of nitrate, in another 3-7 days.

To build up a population of nitrifiers in a culture it is necessary to add more ammonia at intervals as the supply is used up, and also more carbonate to keep the medium alkaline (Winogradsky, 1890). The enrichment culture was maintained for 5 months, during which time four additions of ammonium sulphate solution, totalling $0 \cdot 2 \mathrm{~g} .\left(\mathrm{NH}_{4}\right)_{2} \mathrm{SO}_{4}$, and one addition of $0 \cdot 1 \mathrm{~g} . \mathrm{CaCO}_{3}$ were made to it.

Transfers on liquid media. Several replicate subcultures were made on medium A from the enrichment culture; but after two transfers on this medium some of the replicates failed to nitrify, and it was therefore decided to modify the medium. A more dilute medium, made up in glass-distilled water with a trace element mixture, was tried for two more transfers, but again some of the replicate cultures failed. It was thought that pyrophosphate in the dipotassium phosphate used might be causing the failure, and so the solid dipotassium phosphate was replaced by a solution of potassium dihydrogen phosphate, previously boiled, cooled and made up to volume. The resulting medium $B$ was satisfactory.

Medium $B$ was made up as follows: $\mathrm{NaCl}, 0.3 \mathrm{~g} .3 \mathrm{MgSO}_{4} .7 \mathrm{H}_{2} \mathrm{O}, 0 \cdot 14 \mathrm{~g}$; $\mathrm{FeSO}_{4} .7 \mathrm{H}_{2} \mathrm{O}, 0.03 \mathrm{~g}$; $\left(\mathrm{NH}_{4}\right)_{2} \mathrm{SO}_{4}, 0.66 \mathrm{~g}$; d dissolved in $90 \mathrm{ml}$. glass-distilled water. $\mathrm{KH}_{2} \mathrm{PO}_{4}(0 \cdot 1 \mathrm{M}), 10 \mathrm{ml}$. (previously boiled); 'A-Z' trace element mixture, $1 \mathrm{ml}$., total volume, $101 \mathrm{ml}$. 
Of this solution $10 \mathrm{ml}$. were diluted to $100 \mathrm{ml}$. for use, and $1.0 \mathrm{~g}$. calcium carbonate added. The medium was distributed in shallow layers in conical flasks ( $20 \mathrm{ml}$. lots in $250 \mathrm{ml}$. flasks) and sterilized by autoclaving. The ' $A-Z$ ' trace element mixture (Hoagland \& Snyder, 1933) contains: $\mathrm{LiSO}_{4}, 0.01 \mathrm{~g}$.; $\mathrm{CuSO}_{4}, 0.02$ g.; $\mathrm{ZnSO}_{4}, 0.02$ g.; $\mathrm{H}_{3} \mathrm{BO}_{4}, 0.22 \mathrm{~g}$.; $\mathrm{Al}_{2}\left(\mathrm{SO}_{4}\right), 0.02 \mathrm{~g}$.; $\mathrm{SnCl}_{2}, 0.01 \mathrm{~g}$; $\mathrm{MnCl}_{2}, 0.14$ g.; $\mathrm{NiCl}_{2}, 0.02$ g.; $\mathrm{CoSO}_{4}, 0.02 \mathrm{~g}$.; $\mathrm{TiCl}_{4}$ (15\% solution), $0.13 \mathrm{ml}$.; $\mathrm{KI}, 0.01 \mathrm{~g}$.; $\mathrm{KBr}, 0.01 \mathrm{~g}$; d distilled water, $360 \mathrm{ml}$.

The medium as used had the approximate composition: $\left(\mathrm{NH}_{4}\right)_{2} \mathrm{SO}_{4}, 0.005 \mathrm{M}$; $\mathrm{NaCl}, 0.005 \mathrm{M} ; \mathrm{KH}_{2} \mathrm{PO}_{4}, 0.001 \mathrm{M} ; \mathrm{MgSO}_{4}, 0.001 \mathrm{M} ; \mathrm{FeSO}_{4}, 0.0001 \mathrm{M}$.

Medium $B$ has now been in use for 2 years and twenty-four successive transfers have been made on it without any loss of nitrifying activity. The twenty-fourth transfer formed $100 \mathrm{mg}$. nitrite nitrogen/l. in 7 days, and converted it all to nitrate in 5 days more. A culture of the twenty-fourth transfer was plated on nutrient (peptone meat extract) agar and found to contain at least five contaminating species of bacteria and one actinomycete. As pointed out by Omeliansky (1899a) and by Gibbs (1919), it is impossible to obtain nitrifiers in pure culture by simple serial transfers in liquid medium.

Preparation of material for isolation. As a first step in the isolation of Nitrosomonas, the population of nitrifiers in a subculture of the twenty-fifth transfer was built up by successive additions of ammonium sulphate and calcium carbonate over a period of 4 months. At the end of this time, microscopic examination of the culture showed a large number of bacteria adhering to the calcium carbonate particles at the bottom of the flask. The next step was the removal of the bacteria from the chalk debris with a stream of carbon dioxide. A $1 \mathrm{ml}$. sample of liquid culture was added to $9 \mathrm{ml}$. saline $(0.75 \%$ $\mathrm{NaCl}$ ) in a sterile test-tube, through the cork of which was a narrow glass tube reaching to the bottom, with its end drawn out and coiled horizontally. Through this distributing tube a rapid stream of bubbles of carbon dioxide, generated in a Kipp's apparatus and washed through distilled water, was passed for $\mathbf{3 0}$ min. The contents of the tube were allowed to settle, and $1 \mathrm{ml}$. samples of the supernatant carefully removed with sterile pipettes and used to inoculate poured plates of silica gel.

Plating on silica gel. A silica gel suitable for poured plates was prepared by dialysing a mixture of sodium silicate and hydrochloric acid for 3 days against distilled water, sterilizing the resulting silica sol by filtration, and setting the gel by adding a solution of nutrient salts (Kingma Boltjes, 1935).

Concentrated sodium silicate solution (10 ml.; British Drug Houses Ltd.) was mixed by gentle heating with about $20 \mathrm{ml}$. distilled water, and the volume made up to $100 \mathrm{ml}$. Concentrated hydrochloric acid $(54 \mathrm{ml}$.) and distilled water ( $46 \mathrm{ml}$.) were mixed in a large beaker. Both solutions were cooled, and the silicate solution then poured gradually into the acid and well mixed. The mixture was poured into cellophan bags, which were suspended in cylinders full of distilled water for 3 days. The water in the cylinders was changed six or seven times, and at the end of 3 days it gave no reaction, or only a very faint clouding, with silver nitrate. During the dialysis the silica sol took up water, and the final volume was about $250 \mathrm{ml}$. The sol was sterilized by filtration 
through a Ford SB pad; it must be used at once after filtration, as it gels spontaneously in about $90 \mathrm{~min}$.

To make a poured plate, the following were added in succession to a sterile Petri dish: (1) the inoculum; (2) $1 \mathrm{ml}$. of the following solution, sterilized by autoclaving: $\mathrm{NaCl}, 2.0$ g.; $\mathrm{MgSO}_{4}, 0.5$ g.; $\mathrm{Na}_{2} \mathrm{HPO}_{4}, 12.0$ g.; $\mathrm{KH}_{2} \mathrm{PO}_{4}, 6.0$ g.; $\mathrm{FeSO}_{4}, 0.01$ g.; $\mathrm{MnSO}_{4}, 0.01$ g.; $\mathrm{NaHCO}_{3}, 1.0$ g.; tap water, $100 \mathrm{ml}$.; (3) $1 \mathrm{ml}$. of a $5 \%$ solution of ammonium sulphate, also autoclaved; (4) $10 \mathrm{ml}$. filtered silica sol. The plate was rotated to mix the contents, which set to a clear gel in about $10 \mathrm{~min}$. at room temperature.

\section{The isolation of ammonia-oxidizing bacteria}

Silica gel plates were inoculated with the carbon dioxide-treated supernatant, and also with a ten-fold dilution of it in saline. Other plates were inoculated with dilutions $(1 / 10,000,1 / 100,000$ and $1 / 1,000,000)$ made from the culture without carbon dioxide treatment. The plates were incubated at $25^{\circ}$ for a fortnight. They were then found to be covered with numerous tiny colonies, of a peculiar glassy compact appearance, and about $100 \mu$. in diameter. Some of the plates were contaminated by small colonies of an actinomycete, probably a Micromonospora. The position of a few well-shaped and well-separated colonies was marked with indian ink under the low power of a microscope. The colonies were picked by hand from below, with a Pasteur pipette freshly drawn out in the flame to a fine point for each picking, and each colony was placed in $5 \mathrm{ml}$. of medium $B$ in a $50 \mathrm{ml}$. flask. After incubation at $25^{\circ}$ for 14 to 21 days, five of the flasks contained nitrite in quantity.

One of these five flasks was contaminated with an actinomycete, and was discarded. The other four, which contained only bacteria, were all from the carbon dioxide-treated material. As a test for purity, a loopful was streaked on nutrient agar. Two of the cultures, from the undiluted supernatant, gave no growth on nutrient agar in 3 weeks, and were therefore probably pure. They were plated again on silica gel, in dilutions of $1 / 100$ and $1 / 10,000$. The 1/100 dilution gave innumerable very tiny colonies, of about $20 \mu$. diameter. The higher dilution gave fewer and better developed colonies, all of the same kind (see Pl. 1). Subcultures into medium B produced $100 \mathrm{mg}$. nitrite nitrogen/l. in 6 days, and there was no further oxidation to nitrate. It may therefore be assumed that these two cultures were pure cultures of an ammonia-oxidizing bacterium.

\section{Description of organism isolated}

The bacteria in the two cultures were exactly alike. They were small oval cells, usually single, but occasionally two to four were joined end to end. Measurements on a wet preparation stained with acetic aniline blue gave the length of the cells as $1 \cdot 2-1 \cdot 7 \mu$., and the breadth as $1 \cdot 0-1 \cdot 2 \mu$. They were nonmotile, and so far the motile stage has not been seen. They were difficult to stain by Gram's method because the counterstaining with safranin did not take. Eventually some good preparations were made with carbol erythrosin as a counterstain, which showed the organism to be Gram-negative. There was very 
little alteration in the appearance of a growing liquid culture; the supernatant remained clear, and only after some weeks of incubation did the chalk at the bottom look slightly agglutinated. It could be seen under the microscope that the chalk particles had little masses of bacteria adhering to them. The colonies on silica gel were very small; twenty well-developed colonies measured from 80 to $140 \mu$. in diameter, with an average of $100 \mu$. They were compact and glassily refringent, colourless at first and later becoming brown. They were sometimes round or oval, and sometimes had a curious 'starfish' shape, with projecting points at different levels (see Pl. 1). Except for the lack of motility, these characters correspond to the descriptions of Nitrosomonas europaea given by Winogradsky (1892) and Kingma Boltjes (1935).

I should like to thank Dr Kingma Boltjes for many helpful suggestions, and particularly for showing me colonies of Nitrosomonas spp. I would also like to thank Mr F. A. Skinner for suggesting the use of carbon dioxide, Dr H. Lees for pointing out the toxicity of pyrophosphate, and Dr H. G. Thornton, F.R.S., for his advice and encouragement. My thanks are also due to Mr Victor Stansfield for the photograph, to Miss Mabel Dunkley for preparing the typescript, and to Miss Enid Wilsher, Miss Vera Stock and Miss Marion Chappell for technical assistance.

\section{REFERENCES}

Bömeke, H. (1939). Beiträge zur Physiologie nitrifizierender Bakterien. Arch. Mikrobiol. 10, 385.

Bonazzi, A. (1919). On nitrification: III. The isolation and description of the nitrite ferment. Bot. Gaz. 68, 194.

Bouluanger, E. \& Massol, L. (1903). Études sur les Microbes Nitrificateurs. Ann. Inst. Pasteur, 17, 492.

Enget, H. \& Skaldau, W. (1987). Die Reincultur nitrifizierender Bakterien. Z Z $b l$. Bakt. (2. Abt.), 97, 305.

Frankland, P. F. \& Frankland, G. (1890). The nitrifying process and its specific ferment. Philos. Trans. B, 181, 107.

GrbBs, W. M. (1919). The isolation and study of nitrifying bacteria. Soil Sci. 8, 427.

Hanks, J. H. \& Weintraub, R. L. (1936). The pure culture isolation of ammoniaoxidising bacteria. J. Bact. $32,653$.

HeubüLt, J. (1929). Untersuchungen über Nitritbakterien. Planta, 8, 398.

Hoagland, D. R. \& SNyder, W. C. (1933). Nutrition of strawberry plants under controlled conditions. Proc. Amer. Soc. hort. Sci. 30, 288.

IMŠENECKI, A. A. (1946). Symbiosis between myxobacteria and nitrifying bacteria. Nature, Lond., 157, 877.

Kingma Boltues, T. Y. (1934). Onderzoekingen over nitrificeerende Bacterien. Proefschrift, Delft.

Kingma BoltJes, T. Y. (1935). Untersuchungen über die nitrifizierenden Bakterien. Arch. Mikrobiol. 6, 79.

NeLson, D. H. (1931). Isolation and characterisation of Nitrosomonas and Nitrobacter. Zbl. Bakt. (2. Abt.), 83, 280.

Omeliansky, V. (1899a). Über die Isolierung der Nitrifikationsmikroben aus dem Erdboden. Zbl. Bakt. (2. Abt.), 5, 537.

Omeliansky, V. (1899b). Magnesia-Gipsplatten als neues festes Substrat für die Kultur der Nitrifikations-organismen. Z Zbl. Bakt. (2. Abt.), 5, 652.

Rubentschik, L. (1929). Zur Nitrifikation bei hohen Salzkonzentration. Z Zbl. Bakt. (2. Abt.), 77, 1. 
Journal of General Microbiology, Vol. 4, No. 2

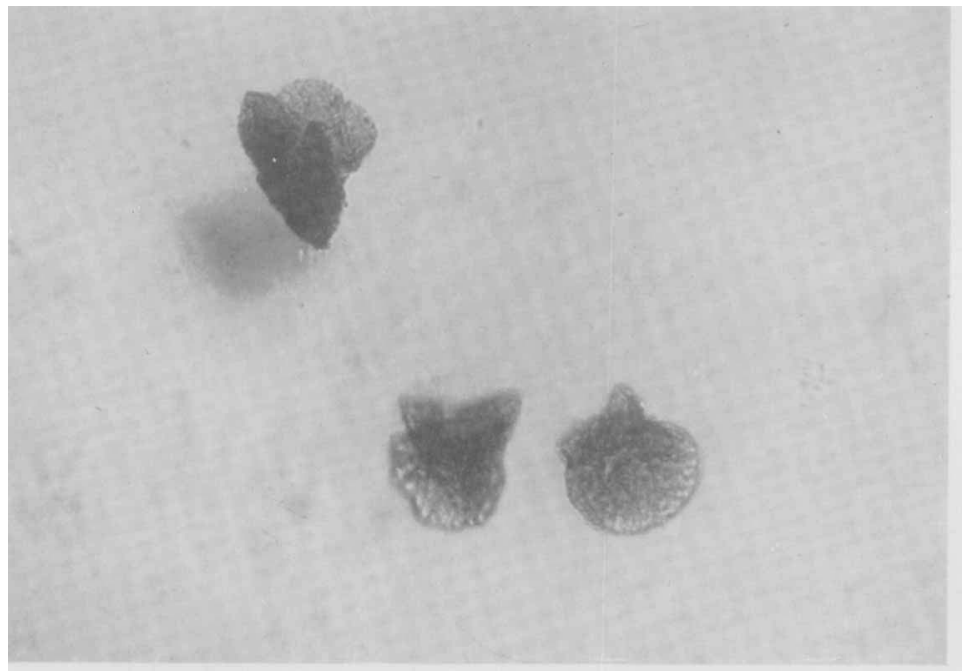

J. Meiklejohn-Pure culture of N. europaea. Plate 1 
Schloesing, T. \& MünTz, A. (1877). Sur la nitrification par les ferments organisés. C.R. Acad. Sci., Paris, 84, 301.

Tchan, Y. T. (1947). Contribution à l'Étude de l'Influence de l'Hyposulfite de Sodium sur quelques groupes de Microorganismes utiles du Sol. Ann. Inst. Pasteur, 73, 242.

Warington, R. (1891). On nitrification. (Part IV.) J. Chem. Soc. 59, 484.

WinogradsKy, S. (1890). Recherches sur les Organismes des la Nitrification. (Parts 1-3.) Ann. Inst. Pasteur, 4, 213, 257, 760.

Winogradsky, S. (1891). Recherches sur les Organismes de la Nitrification. (Parts 4-5.) Ann. Inst. Pasteur, 5, 92, 577.

Winogradsky, S. (1892). Contribution à la Morphologie des Organismes de la Nitrification. Arch. Sci. biol. (St Petersburg), 1. (Abstract in Ann. Inst. Pasteur, 6, 459.)

Winogradsky, S. (1904). Die Nitrifikation. In LAFar, F. (1904-6). Handbuch der Technischen Mykologie, Vol. III. Jena: Gustav Fischer.

Winogradsky, S. (1935). The method in soil microbiology as illustrated by studies on Azotobacter and the nitrifying organisms. Soil Sci. 40, 59.

Winogradsky, S. \& Winogradsky, H. (1933). Etudes sur la Microbiologie du Sol: (7) Nouvelles Recherches sur les organismes de la Nitrification. Ann. Inst. Pasteur, 50, 350.

ZoBELx, C. E. (1932). Factors influencing the reduction of nitrates and nitrites by bacteria in semi-solid media. J. Bact. 24, 273.

\section{EXPLANATION OF PLATE}

Three colonies of Nitrosomonas europaea on silica gel, showing 'starfish' shape. $(\times 120$.)

(Received 14 July 1949) 